International Journal of Social Science and Economic Research

ISSN: 2455-8834

Volume:05, Issue:11 "November 2020"

\title{
UNDERSTANDING PIRACY AT THE UNIVERSITY LEVEL
}

\author{
Amit Kumar Jha \\ University of Delhi \\ DOI: 10.46609/IJSSER.2020.v05i11.012 URL: https://doi.org/10.46609/IJSSER.2020.v05i11.012
}

\begin{abstract}
This paper discuses many forms of piracy prevailing in the society i.e cinematographic piracy, music and sound recording piracy, software piracy and books piracy. This is on the basis of surveys of students who are currently enrolled in various faculties in the University of Delhi. The paper brings out a broad piracy analysis where piracy is defined on four aspects i.e. unauthorised downloading, unauthorised duplication, purchasing pirated materials and photocopying of books. The paper also lists important factors governing piracy.
\end{abstract}

Keywords: Piracy, unauthorised downloading, unauthorised duplication, purchasing pirated materials and photocopying of books.

\section{Introduction}

Piracy is rampant in probably all spheres of life. These days one just needs an internet to download all kind of pirated movies, music, software and books. It just like a click of the mouse can take a person in the virtual world of fake products. This is costing the film industry, music industry, software makers and publishers, billions of dollars. This is also hampering the innovative potential of the society as a whole as they realise that their hard work of many years are selling for a penny in the market.

This paper tries to unlock many facets of piracy prevailing in the society i.e cinematographic piracy, music and sound recording piracy, software piracy and books piracy. This is based on the surveys of students who are currently enrolled in various faculties in the University of Delhi. The survey is based on a detailed multistage stratified sampling as discussed in the next section. The paper brings out a comprehensive piracy analysis where piracy is defined on four aspects i.e. unauthorised downloading, unauthorised duplication, purchasing pirated materials and photocopying of books. Along with these four aspects of piracy, the paper lists some of the important features governing piracy like the frequency of using file sharing services and how the purchasing of original materials is been affected by it; any intention of using it in near future, views on peer piracy, awareness of the legal consequences of indulging in piracy and reasons for 


\section{International Journal of Social Science and Economic Research}

ISSN: $2455-8834$

Volume:05, Issue:11 "November 2020"

still persisting with it, role of affordable internet plans in aggravating piracy and finally, the reasons for not indulging in piracy.

The next section brings out a detailed sampling analysis, followed by data description in section 3 and section 4 brings out the piracy analysis.

\subsection{Sampling}

An important sampling issue is to look for an estimator of a population parameter which captures the notable features of the population. If the population under study is homogeneous with respect to its characteristic, then the scheme of simple random sampling (SRS) provides a representative sample; so that the sample mean, for example, would serve as a good estimator of the population mean (Hansen et al. 1953). However, according to Thompson et al (2012), the variance of the sample mean depends not only on the sample size and sampling fraction but also on the population variance. Therefore, to increase the precision of an estimator, he suggest that one could resort to a sampling scheme which first homogenizes the population by, for example, resorting to stratified sampling. The basic idea behind stratified sampling is to divide the heterogeneous population into subpopulations or smaller groups or strata, such that with respect to the characteristic under study, the sampling units are: (a) homogeneous within each subpopulation; and (b) heterogeneous across the subpopulations. Then, one can treat each subpopulation as a separate population, and draw a sample by SRS from each stratum.

Stratification increases the consistency of the sample results. The increase in accuracy of the sample estimates obtained by stratification depends on the degree of homogeneity that is achieved within each stratum i.e. it depends on how much of the variability in the characteristic being estimated is reflected in the differences across the strata (Kish 1965). Therefore, in establishing stratum boundaries, one should use all the information that helps classify members of the population into groups which vary from one another with respect to the characteristic being measured. But within each stratum the sample will essentially be a probability sample; one cannot use judgment for the selection of the individual sampling units.

However, there are cases where stratification, even though carried out with utmost care does not increase the consistency of the results from a sample. For example, estimating characteristics for less skewed distributions, such as for estimating proportions of units having specified characteristics, the importance of stratification can easily be exaggerated (Hansen et al. 1953). By implication, one should try and avoid these pitfall situations.

\subsection{Advantages of Stratified Sampling}

Following is the brief discussion of major advantages of stratified sampling. 
International Journal of Social Science and Economic Research

ISSN: 2455-8834

Volume:05, Issue:11 "November 2020"

(1) The careful exploration of a few strata (Cochran 2007) is beneficial when data of high precision is required for certain parts of the population.

(2) One can consider administrative convenience in stratified sampling (Levy and Lemeshow, 2013). For instances, in taking a sample of villages from a big state, it is convenient to consider the districts as strata, so that the administrative structure at the district level is utilised for the purpose of data collection. In national level surveys, such convenience and the convenience in organization of field work are important aspects.

(3) One can acquire full cross-section of population through stratified sampling. It is possible that a large part of the population may remain unrepresented in SRS. However, stratified sampling allows one to draw a sample representing different cross-sections of the population up to the desired extent.

(4) The use of stratification is of greater significance in case of skewed population since one may apply larger weights to few extremely large units.

(5) If population is large, then it is appropriate to sample separately from the strata rather than the whole population.

\subsection{Procedure of Stratified Sampling}

Suppose $\mathrm{K}$ is the number of strata into which the population under consideration is divided and $\mathrm{N}$ represents the total number of units in the entire population. Let $\mathrm{N}_{h}$ represent the numbers in the $\mathrm{h}^{\text {th }}$ stratum. Then,

$\mathrm{N}=\sum_{h}^{K} N_{h}=\mathrm{N}_{1}+\mathrm{N}_{2}+\ldots . .+\mathrm{N}_{\mathrm{k}}$

Similarly, suppose $n_{h}$ and $\sum_{h}^{K} n_{h}$ are the sizes of the sample drawn from the $\mathrm{h}^{\text {th }}$ stratum and total size of the sample drawn from all strata, respectively. The subscript i represents the individual sampling unit; so that the value of a characteristic $X$ of the $i_{\text {th }}$ sampling unit in the $h_{\text {th }}$ stratum is designated by $\mathrm{X}_{\mathrm{hi}}$.

Once the decision on the strata and the size of sample to be taken from each stratum is finalised, the sample is selected by simple random sampling (SRS) within each stratum. That is, each stratum is treated as a population from which a simple random sample is selected. Sometimes the sample is selected from the strata in such a way that the sampling fraction is the same for all strata, such a sample is called a proportionate stratified sample. It is, however, not necessary that the same proportion is included from each stratum. The proportion in the sample from the $h_{t h}$ stratum is equal to $f_{h}=n_{h} / N_{h}$, and this fraction in the sample may vary widely, slightly, or not at all, from one stratum to the next (Hansen et al, 1953). 
International Journal of Social Science and Economic Research

ISSN: 2455-8834

Volume:05, Issue:11 "November 2020"

\subsection{Choice of Sample Sizes in Different Strata - Allocation Problem}

One can choose the sample in two ways: (1) so as to minimize the cost of survey for a stated precision; and (2) so as to maximize the precision for a specified cost. According to Kish (1965), the sample size cannot be determined by minimizing both the variability and cost simultaneously. The cost function is directly related to the sample size, whereas variability is inversely related to the sample size. Therefore, based on different criteria, some allocation measures are discussed below:

\section{Equal allocation}

Under this method, one can choose the sample size to be same for all the strata, and then draw samples of identical size from each stratum. Let $n$ be the sample size and $K$ be the number of strata, then $n_{h}=n / K$.

\section{Proportional allocation}

For given $\mathrm{h}$, one can select $\mathrm{n}_{\mathrm{h}}$ such that it is proportional to stratum size, i.e.

$$
\mathrm{n}_{\mathrm{h}} / \mathrm{n}=\mathrm{N}_{\mathrm{h}} / \mathrm{N} \quad \text { or } \quad \mathrm{n}_{\mathrm{h} / \mathrm{N}} \mathrm{N}_{\mathrm{h}} \mathrm{n} / \mathrm{N} \quad \text { or } \mathrm{f}_{\mathrm{h}}=\mathrm{f}
$$

This implies that sampling fraction is identical in every stratum. This allocation is defined as stratification with proportional allocation of $n_{h}$. It provides a self-weighting sample. If several estimates are made, self-weighting sample is time saving (Cochran, 2007). The relative improvement by using proportionate stratified sampling as compared to simple random sampling is $\left(\sigma_{b}^{2}-s_{w}^{2} / \bar{N}\right) / s^{2}$ (Hansen et al, 1953) which, in turn, is nearly equal to the measure of homogeneity within the strata.

\section{Optimum allocation}

Often, it is argued that proportional allocation is not the sort of allocation that results in an estimator with the lowest variance among all likely ways of allocating a sample of $n$ elements among the K strata. Levy \& Lemeshow (2013) show that the allocation of $\mathrm{n}$ sample units into each stratum yields an estimated mean (or total, or proportion) for a variable $\mathrm{X}$ having lowest variance is given by $n_{h}=\left(N_{h} \sigma_{h x} / \sum_{h=1}^{K} N_{h} \sigma_{h x}\right)(n)$.

However, there are some limitations of the optimum allocation. The prior knowledge of $\sigma_{h x}$ is needed to know $n_{h}$. The problem in the application of optimum sampling theory to strata is the lack of information of the variance of the characteristic under consideration for each stratum. The fact is that these variances are not well known. Sometimes they can be assessed very roughly, and at best one can deal with approximations. Sometimes one can derive from prior knowledge, an idea of the relative sizes of the standard deviations in the different strata. If 
International Journal of Social Science and Economic Research

ISSN: 2455-8834

Volume:05, Issue:11 "November 2020"

one does not know the values of $\mathrm{S}_{1}, \mathrm{~S}_{2} \ldots \mathrm{S}_{\mathrm{K}}$, but does know some numbers proportional to them, $\mathrm{kS}_{1}, \mathrm{kS}_{2}, \ldots \mathrm{kS}_{\mathrm{K}}$, then one can get exactly the same optimum allocation of the sample to the different strata. Thus, even a rough knowledge of the relative magnitudes of the standard deviations in various strata is adequate. Hansen et al (1953) note that there is an increase in the precision with the use of optimum values for the $n_{h}$ as compared to the use of proportionate sampling and the relative gain is in the range of $V^{2} \tilde{s}_{h} / 1+V^{2} \tilde{s}_{h}$. Nevertheless, results do not vary much with moderate deviations from the optimum.

Now, in order to incorporate the above analysis, it is important that one possess full information of the population. In this study, the population consists of students of the University of Delhi. The sampling framework is based on the University of Delhi's Annual Reports. The paper uses a multi-stage stratified sampling procedure, where the stratification is based on the division of the student population according to their enrolment in various faculties. So the different university faculties form different strata in the survey. This stratification facilitates sample selection, which has been done on the basis of proportional allocation. One cannot go for optimal allocation due to the lack of knowledge of standard errors for each stratum of characteristics under study. Nor does there exist any prior experience of handling such data, or indeed any proxies (for piracy) to calculate approximate values for standard errors. One also observes that the use of proportional sampling may result in too small a sample for some strata, as is clear from Table 2, therefore over-sampling is done in some segments of the population, so as to avoid under-representation of the population of those segments.

Using the proportionate sample rule, the sample size per stratum has been measured as $\mathrm{n}_{\mathrm{h}}=$ $\mathrm{N}_{\mathrm{h}}{ }^{*} \mathrm{n} / \mathrm{N}$, where $\mathrm{N}_{\mathrm{h}}$ is number of students per stratum, $\mathrm{n}=1000$ is the sample size, and $\mathrm{N}=615542$ is the total number of students in the University of Delhi. Note that the sample size 1000 has been taken for convenience.

\subsection{Strata Formation}

Next is the discussion on the formulation of different strata, which is based on different faculties of the University of Delhi:

\subsubsection{The Undergraduate Level:}

According to the University of Delhi's $91^{\text {st }}$ annual report 2013-2014, there are thirteen faculties at the under-graduate level. These are:

1. Arts,

2. Ayurveda \& Unani Medicine,

3. Homoeopathic Medicine, 


\section{International Journal of Social Science and Economic Research}

ISSN: 2455-8834

Volume:05, Issue:11 "November 2020"

4. Inter-Disciplinary,

5. Mathematical Sciences,

6. Medical Sciences,

7. Music \& Fine Arts,

8. Sciences,

9. Social Sciences,

10. Applied Social Sciences \& Humanities,

11. Commerce \& Business,

12. Technology,

13. Education.

However, because of low enrolment of students in some faculties, and following standard international faculty definitions, one decides to club some of the faculties which are similar in nature. For instance, Faculty of Education and Applied Social Sciences \& Humanities are clubbed into Faculty of Social Sciences. The Faculty of music and fine arts is clubbed into Faculty of Arts. Faculties of Ayurveda \& Unani Medicine, and Homoeopathic Medicine, are clubbed into Faculty of Medical Sciences. Finally, the faculties of Science, Technology, InterDisciplinary Sciences and Mathematical Sciences are clubbed into Faculty of Science and Technology. Therefore, five faculties are created out of the original thirteen. The preferred categories are:

- Faculty of Social Sciences

- Faculty of Arts

- Faculty of Medical Sciences

- Faculty of Science and Technology

- Faculty of Commerce

\subsubsection{The Postgraduate Level}

The University of Delhi's 91st annual report 2013-2014 lists fifteen faculties at the postgraduate level which are:

1. Arts,

2. Ayurveda \& Unani Medicine, 
3. Homoeopathic Medicine,

4. Inter-Disciplinary,

5. Mathematical Science,

6. Medical Science,

7. Music \& Fine Arts,

8. Science,

9. Social Sciences,

10. Applied Social Science \& Humanities,

11. Commerce \& Business,

12. Technology,

13. Education,

14. Law,

15. Management

Further, the report mentions that there are thirteen faculties offering Doctor of Philosoply (Ph.d) and nine offering Master of Philosoply (M.Phil.) degrees, respectively. The Faculty of Management is included into Faculty of Commerce. For rest of the faculties, same clubbing procedure is followed as was done in the case of under-graduate levels. Thus, six strata are formed, as given below:

(1) Faculty of Social Sciences

(2) Faculty of Arts

(3) Faculty of Medical Sciences

(4) Faculty of Science and Technology

(5) Faculty of Commerce

(6) Faculty of Law

The next step is the selection of a sample of 1350 students from across these different faculties at the undergraduate and postgraduate levels. Even though the initial plan was to survey 1000 students, over-sampling is done to prevent under-representation of certain categories.

\section{Data Description}


International Journal of Social Science and Economic Research

ISSN: 2455-8834

Volume:05, Issue:11 "November 2020"

Table 1 shows the number of students enrolled in different faculties, for the year 2013-14, in the University of Delhi.

Table 1: Faculty-wise Population Distribution of Students for the Year 2013-14

\begin{tabular}{|l|l|l|l|l|l|l|l|}
\hline & \multicolumn{3}{|c|}{ Male } & \multicolumn{3}{c|}{ Female } & \\
\hline Faculty & Regular & $\begin{array}{l}\text { Non- } \\
\text { Regular }\end{array}$ & $\begin{array}{l}\text { Male } \\
\text { Total }\end{array}$ & Regular & $\begin{array}{l}\text { Non- } \\
\text { Regular }\end{array}$ & $\begin{array}{l}\text { Female } \\
\text { Total }\end{array}$ & Total $\left(\mathrm{N}_{\mathrm{h}}\right)$ \\
\hline \multicolumn{6}{|c|}{ UNDERGRADUATE STUDENTS } \\
\hline
\end{tabular}

\begin{tabular}{|l|l|l|l|l|l|l|l|}
\hline Social Sciences & 16764 & 7276 & 24040 & 22113 & 8680 & 30793 & 54833 \\
\hline Arts & 22693 & 108781 & 131474 & 32033 & 136386 & 168419 & 299893 \\
\hline Medical Sciences & 1558 & 0 & 1558 & 2228 & 0 & 2228 & 3786 \\
\hline $\begin{array}{l}\text { Science \& } \\
\text { Technology }\end{array}$ & 24068 & 0 & 24068 & 22432 & 0 & 22432 & 46500 \\
\hline Commerce & 19367 & 85053 & 104420 & 19098 & 58931 & 78029 & 182449 \\
\hline Total & $\mathbf{8 4 4 5 0}$ & $\mathbf{2 0 1 1 1 0}$ & $\mathbf{2 8 5 5 6 0}$ & $\mathbf{9 7 9 0 4}$ & $\mathbf{2 0 3 9 9 7}$ & $\mathbf{3 0 1 9 0 1}$ & $\mathbf{5 8 7 4 6 1}$ \\
\hline & \multicolumn{7}{|c|}{ POSTGRADUATE STUDENTS }
\end{tabular}

\begin{tabular}{|l|l|l|l|l|l|l|l|}
\hline Social Sciences & 5815 & 251 & 6066 & 3526 & 729 & 4255 & 10321 \\
\hline Arts & 1271 & 163 & 1434 & 2082 & 809 & 2891 & 4325 \\
\hline Medical Sciences & 958 & 0 & 958 & 717 & 0 & 717 & 1675 \\
\hline $\begin{array}{l}\text { Science and } \\
\text { Technology }\end{array}$ & 1523 & 0 & 1523 & 2618 & 75 & 2693 & 4216 \\
\hline Commerce & 1428 & 548 & 1976 & 678 & 867 & 1545 & 3521 \\
\hline Total & $\mathbf{1 0 9 9 5}$ & $\mathbf{9 6 2}$ & $\mathbf{1 1 9 5 7}$ & $\mathbf{9 6 2 1}$ & $\mathbf{2 4 8 0}$ & $\mathbf{1 2 1 0 1}$ & $\mathbf{2 4 0 5 8}$ \\
\hline & & \multicolumn{7}{|l|}{ M.Phil/ Ph.D } & & & \\
\hline Social Sciences & 355 & 0 & 355 & 457 & 0 & 457 & 812 \\
\hline Arts & 605 & 0 & 605 & 730 & 0 & 730 & 1335 \\
\hline
\end{tabular}


International Journal of Social Science and Economic Research

ISSN: 2455-8834

Volume:05, Issue:11 "November 2020"

\begin{tabular}{|l|l|l|l|l|l|l|l|}
\hline Medical Sciences & 36 & 0 & 36 & 49 & 0 & 49 & 85 \\
\hline $\begin{array}{l}\text { Science and } \\
\text { Technology }\end{array}$ & 632 & 0 & 632 & 951 & 0 & 951 & 1583 \\
\hline Commerce & 73 & 0 & 73 & 135 & 0 & 135 & 208 \\
\hline Total & $\mathbf{1 7 0 1}$ & $\mathbf{0}$ & $\mathbf{1 7 0 1}$ & $\mathbf{2 3 2 2}$ & $\mathbf{0}$ & $\mathbf{2 3 2 2}$ & $\mathbf{4 0 2 3}$ \\
\hline & & & & & & & \\
\hline
\end{tabular}

Source: University of Delhi $91^{\text {st }}$ Annual Report

Table 2 gives the sample proportions, which are close to the actual population proportions. The female representation in the sample is around $57 \%$ as compared $43 \%$ male students. There are approximately $74 \%$ students in undergraduate courses, $16 \%$ in post-graduate courses, and $10 \%$ pursuing research (M.Phil. \& Ph.D.). The non-regular students' comprise approximately $50 \%$ of the total undergraduate students, $3 \%$ of the post-graduate students, and $0 \%$ of the research students. As a share of the entire student body at the University, approximately $10 \%$ belong to the Faculty of Social Sciences, about $40 \%$ to the Faculty of Arts, about 3\% to the Faculty of Medical Sciences, about $11 \%$ to the Faculty of Science \& Technology, about $28 \%$ to the Faculties of Commerce and Management, and some $7 \%$ to the Faculty of Law.

Table 3 presents the distribution of students across different faculties, classified on the basis of gender, degree levels and whether the student is enrolled in regular courses, or the School of Open Learning (SOL), or the Non-Collegiate Women's Education Board (NCWEB). The sample is dominated by students enrolled in graduate courses, followed by post-graduate students, and then researcher students. This is in conformity with the University of Delhi population characteristics. The table shows fewer observations for students in the medical sciences, and zero observations for males in the NCWEB centre, both of which are justifiable on the basis of the parent population's characteristics. Overall, the most sample observations are for Faculty of Arts and Commerce, followed by the Faculty of Social Sciences. 
International Journal of Social Science and Economic Research

ISSN: 2455-8834

Volume:05, Issue:11 "November 2020"

\begin{tabular}{|l|l|l|}
\hline \multicolumn{3}{|c|}{ Table 2: Sample vs Population size for Various Stratum } \\
\hline Students & $\begin{array}{l}\text { Sample size } \\
\left(\mathrm{n}_{\mathrm{h}} / \mathrm{n} \%\right)^{1}\end{array}$ & $\begin{array}{l}\text { Population Size } \\
\left(\mathrm{N}_{\mathrm{h}} / \mathrm{N} \%\right)^{2}\end{array}$ \\
\hline \multicolumn{3}{|c|}{ Male vs Female } \\
\hline Male & $585(43 \%)$ & $299218(48.61 \%)$ \\
\hline Female & $765(57 \%)$ & $316324(51.38 \%)$ \\
\hline Total & 1350 & 615542 \\
\hline \multicolumn{2}{|c|}{ Regular vs Non Regular Students } \\
\hline Non Regular Under- Graduate & $671(50 \%)$ & $20616(3.34 \%)$ \\
\hline Regular Under- Graduate & $333(25 \%)$ & $182354(29.62 \%)$ \\
\hline Regular Post- Graduate & $179(13.2 \%)$ & $0(0 \%)$ \\
\hline Non- Regular M.phil/ Ph.D & $0(0 \%)$ & $3442(0.55 \%)$ \\
\hline & $40(2.96 \%)$ & $4023(0.65 \%)$ \\
\hline & $127(9.4 \%)$ & \\
\hline
\end{tabular}

${ }^{1} . \mathrm{n}_{\mathrm{h}} / \mathrm{n}$ is the ratio of sample stratum size to total sample size.

${ }^{2}$. $\mathrm{N}_{\mathrm{h}} / \mathrm{N}$ is the ratio of population stratum size to the total population size. 
International Journal of Social Science and Economic Research

ISSN: 2455-8834

Volume:05, Issue:11 "November 2020"

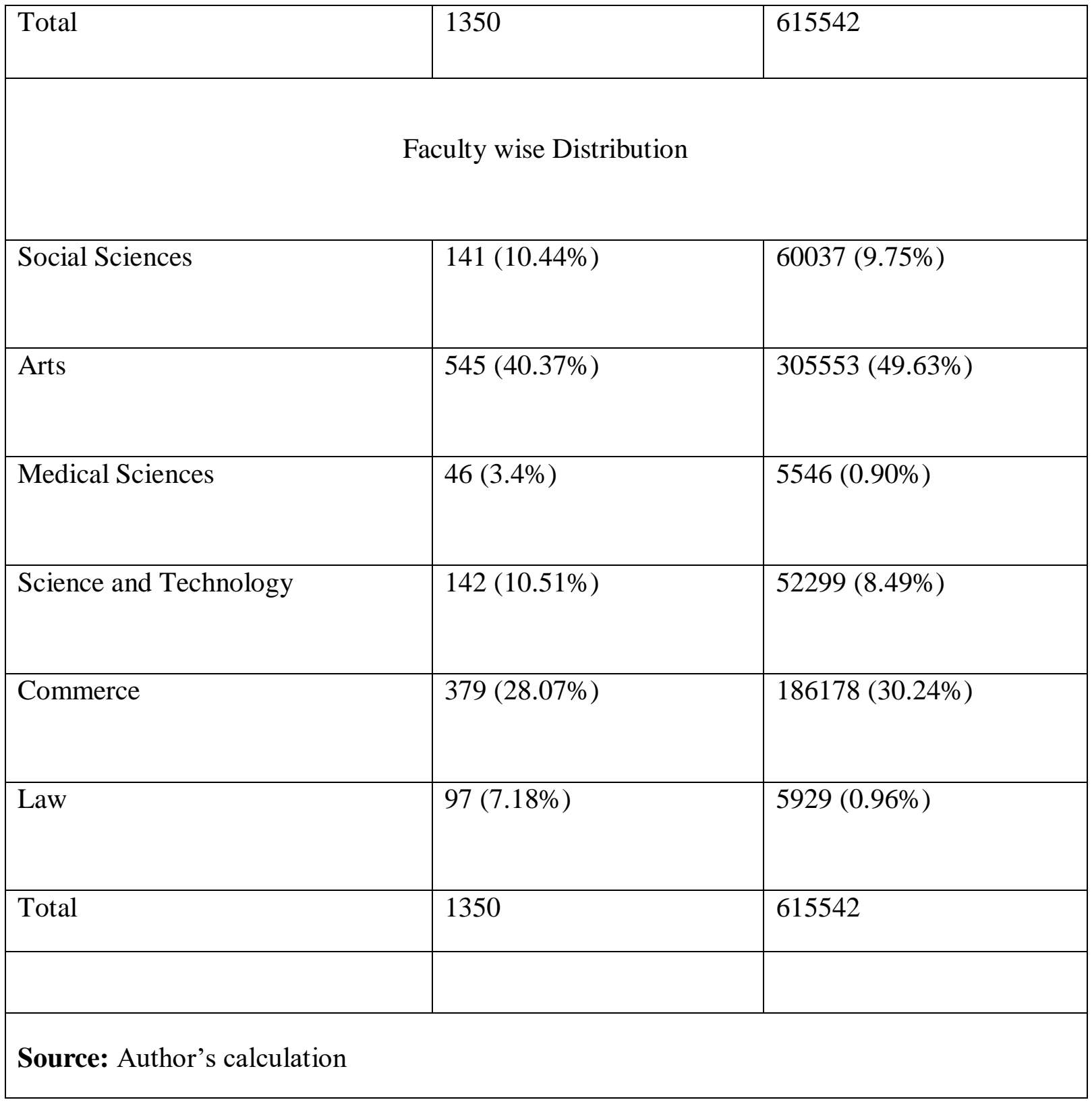

Table 3: Faculty-wise Distribution of Sample of Students for the Year 2017-18

\begin{tabular}{|l|l|l|l|l|}
\hline & MALE & FEMALE & $\begin{array}{l}\text { Total } \\
\text { sample }\end{array}$ & Population \\
\hline
\end{tabular}


International Journal of Social Science and Economic Research

ISSN: 2455-8834

Volume:05, Issue:11 "November 2020"

\begin{tabular}{|l|l|l|l|l|l|l|l|l|}
\hline Faculty & Regular & SOL & NCWEB & Regular & SOL & NCWEB & $\begin{array}{l}\text { size } \\
\text { (Sample } \\
\text { proportions } \\
\%)\end{array}$ & $\begin{array}{l}\text { size } \\
\text { (Population } \\
\text { proportions } \\
\%\end{array}$ \\
\hline $\begin{array}{l}\text { Social } \\
\text { Sciences }\end{array}$ & 37 & 0 & 0 & 48 & 0 & 0 & $85(6.3)$ & $\begin{array}{l}54833 \\
(8.90)\end{array}$ \\
\hline Arts & 34 & 145 & 0 & 21 & 142 & 135 & $477(35.3)$ & $\begin{array}{l}299893 \\
(48.72)\end{array}$ \\
\hline $\begin{array}{l}\text { Medical } \\
\text { Sciences }\end{array}$ & 21 & 0 & 0 & 21 & 0 & 0 & $42(3.11)$ & $3786(0.61)$ \\
\hline $\begin{array}{l}\text { Science \& } \\
\text { Technology }\end{array}$ & 104 & 0 & 0 & 26 & 0 & 0 & $130(9.6)$ & $\begin{array}{l}46500 \\
(7.55)\end{array}$ \\
\hline Commerce & 6 & 83 & 0 & 15 & 21 & 145 & $270(20)$ & $\begin{array}{l}182449 \\
(29.64)\end{array}$ \\
\hline $\begin{array}{l}\text { Grand } \\
\text { Total }\end{array}$ & 202 & 228 & 0 & 131 & 163 & 280 & 1004 & $\begin{array}{l}587461 \\
(95.43)\end{array}$ \\
\hline
\end{tabular}

\section{POSTGRADUATE STUDENTS}

\begin{tabular}{|l|l|l|l|l|l|l|l|l|}
\hline $\begin{array}{l}\text { Social } \\
\text { Sciences }\end{array}$ & 6 & 0 & 0 & 13 & 0 & 0 & $19(1.4)$ & $4392(0.71)$ \\
\hline Arts & 10 & 0 & 0 & 2 & 0 & 0 & $12(0.88)$ & $4325(0.70)$ \\
\hline $\begin{array}{l}\text { Medical } \\
\text { Sciences }\end{array}$ & 2 & 0 & 0 & 2 & 0 & 0 & $4(0.29)$ & $1675(0.27)$ \\
\hline $\begin{array}{l}\text { Science \& } \\
\text { Technology }\end{array}$ & 5 & 0 & 0 & 5 & 0 & 0 & $10(0.74)$ & $4216(0.68)$ \\
\hline $\begin{array}{l}\text { Commerce } \\
\text { Law }\end{array}$ & 33 & 10 & 0 & 4 & 30 & 0 & $77(5.70)$ & $3521(0.57)$ \\
\hline Total & 84 & 10 & 0 & 95 & 30 & 0 & $\begin{array}{l}219 \\
(16.22)\end{array}$ & $\begin{array}{l}24058 \\
(3.90)\end{array}$ \\
\hline
\end{tabular}


International Journal of Social Science and Economic Research

ISSN: 2455-8834

Volume:05, Issue:11 "November 2020"

\begin{tabular}{|l|l|l|l|l|l|l|l|l|}
\hline \multicolumn{7}{|c|}{ M.Phil/ Ph.D } \\
\hline $\begin{array}{l}\text { Social } \\
\text { Sciences }\end{array}$ & 15 & 0 & 0 & 22 & 0 & 0 & $37(2.74)$ & $742(0.12)$ \\
\hline Arts & 25 & 0 & 0 & 31 & 0 & 0 & $56(4.14)$ & $1335(0.21)$ \\
\hline $\begin{array}{l}\text { Medical } \\
\text { Sciences }\end{array}$ & 0 & 0 & 0 & 0 & 0 & 0 & $0(0)$ & $85(0.01)$ \\
\hline S \& T & 1 & 0 & 0 & 1 & 0 & 0 & $2(0.14)$ & $1583(0.25)$ \\
\hline Commerce & 20 & 0 & 0 & 12 & 0 & 0 & $32(2.37)$ & $208(0.03)$ \\
\hline Law & 0 & 0 & 0 & 0 & 0 & 0 & $0(0)$ & $70(0.01)$ \\
\hline Total & 61 & 0 & 0 & 66 & 0 & 0 & $127(9.40)$ & $4023(0.65)$ \\
\hline & & & & & & & & \\
\hline
\end{tabular}

Source: Author's calculations.

Table 4 presents the sample distributions with respect to students' age, income, academic performance, preferred language, and schooling. Approximately $61 \%$ of the students belong to the age category $16-20$, about $24 \%$ to the $21-25$ age-group, and $14 \%$ to the above- 25 years agegroup. The lower two income groups (Rs 0-4000 \& Rs 4001-8000) cover 70\% of the sample population while the rest are in upper two income groups (Rs 8001-12000 \& greater than Rs 12001). Regarding academic performance, the top two groups (marks obtained in the previous exam attended, in the range of $80-90 \%$ \& greater than $90 \%$ ) contain approximately $43 \%$, while the rest fall in the bottom three groups $(<60 \%, 61-70 \%$ and $71-80 \%)$. Approximately $77 \%$ of the students revealed that they prefer to write their exams in the English language, rather than in Hindi. Lastly, $53 \%$ of the sample students did their schooling up till the $10^{\text {th }}$ class from government schools. This proportion reflects the fact that the sample is dominated by nonregular students, who are generally from lower income strata, and obtain their education from government schools.

Table 4: Students' Characteristic

\begin{tabular}{|l|l|}
\hline Age & Number of Students in each strata \\
\hline $16-20$ & 828 \\
\hline
\end{tabular}


International Journal of Social Science and Economic Research

ISSN: 2455-8834

Volume:05, Issue:11 "November 2020"

\begin{tabular}{|l|l|}
\hline $21-25$ & 324 \\
\hline$>25$ & 198 \\
\hline Income & \multicolumn{2}{|l|}{} \\
\hline $0-4000$ & 587 \\
\hline $4001-8000$ & 348 \\
\hline $8001-12000$ & 93 \\
\hline$>12000$ & 322 \\
\hline Academic Performance( Last Degree) & \\
\hline$<60 \%$ & 174 \\
\hline $61-70 \%$ & 403 \\
\hline $71-80 \%$ & 302 \\
\hline Preferred Language & \\
\hline
\end{tabular}


International Journal of Social Science and Economic Research

ISSN: 2455-8834

Volume:05, Issue:11 "November 2020"

\begin{tabular}{|l|l|}
\hline Schooling $\left(\mathbf{1 0}^{\text {th }}\right)$ \\
\hline Government & 710 \\
\hline Non-government & 640 \\
\hline
\end{tabular}

Source: Author's own calculation

Table 5 sheds some light on the household level characteristics of the students in the sample. Approximately $80 \%$ of the households fall in the lower three groups of income $(<2.5$ lakhs, 2.55 lakhs and 5-7.5 lakhs), and rest are in upper two income (7.5-10 lakhs and >10 lakhs) categories. Regarding education of the father, $1.5 \%$ are illiterate, $40 \%$ have a graduate degree, $12 \%$ can boast of a post-graduate degree, while the rest have education up till the higher secondary level. On mother's education, $6.5 \%$ are illiterate, $24 \%$ are graduates, and $7 \%$ possess post-graduate degree. Majority of the mothers of the sample students (59\%) have a higher secondary education.

\begin{tabular}{|l|l|}
\hline \multicolumn{2}{|c|}{ Table 5: Households Characteristic } \\
\hline Household income & Numbers in each strata \\
\hline$<2.5$ lakhs & 378 \\
\hline $2.5-5$ lakhs & 507 \\
\hline $5-7.5$ lakhs & 191 \\
\hline $7.5-10$ lakhs & 140 \\
\hline$>10$ lakhs & 134 \\
\hline Father's education & \\
\hline
\end{tabular}


International Journal of Social Science and Economic Research

ISSN: 2455-8834

Volume:05, Issue:11 "November 2020"

\begin{tabular}{|l|l|}
\hline Illiterate & 21 \\
\hline Till Secondary & 216 \\
\hline Higher secondary & 370 \\
\hline Graduate & 542 \\
\hline Post-graduate and above & 163 \\
\hline Diploma and Professional degree & 28 \\
\hline Mother's education & 88 \\
\hline Illiterate & 431 \\
\hline Till Secondary & 359 \\
\hline Higher secondary & 335 \\
\hline Graduate & 98 \\
\hline Post-graduate and above & \\
\hline Diploma and Professional degree & \\
\hline
\end{tabular}

Source: Author's own calculation

\section{Piracy Statistics}

Let us now consider some statistics related to piracy by the students. Of the total sampled students, $82 \%$ indicated their involvement in some form of movie piracy, $88 \%$ accepted their indulgence in audio piracy, and $94 \%$ in book piracy (Graph 1). However, software piracy rates 


\section{International Journal of Social Science and Economic Research}

ISSN: $2455-8834$

Volume:05, Issue:11 "November 2020"

are lower, with only $37 \%$ indicating their involvement in some form of software piracy. The dominant form of piracy is unauthorised downloading and copying, whereas few still rely on purchasing pirated materials (see Graphs 2, 3, 4 and 5). In terms of piracy of books, the most dominant form is photocopying of entire books (Graph 5).

Approximately $42 \%$ of the respondents are using file sharing services at least once in a week, to download movies, music etc, followed by $18 \%$ and $13 \%$ who are using file sharing services once in a day and month respectively (Table 6). The respondents cited fear of malwares (Table 7) as the most important reason followed by disliking for virtual copies, fear of loss of privacy and no access to computers, for not using file sharing services. Approximately, 83\% of the respondents showed their interest in using file sharing services in near future (Table 8) and $82 \%$ of the respondents agreed that online streaming and file sharing services have actually reduced their purchasing of original materials (Table 9).

When asked about their views on peer piracy (Table 10), majority of them (69\%) stated that they have no problem with their peers engaging in piracy, only $4 \%$ felt offended by it. This seems to suggest the general acceptance of piracy among the people. However when these respondents were warned of the consequences of piracy (Table 11), 74\% agreed to put a pause to piracy and while $25 \%$ stated to continue doing so. This shows that in general, people are unaware of legal consequences of engaging in piracy. For those people who refused to stop doing piracy, majority (71\%) attributed this to overpricing of original materials; followed by easy to find stuffs online, ready availability, saves time as there is no need to visit the store and no prosecution worries (Table 12). Finally, when these respondents are asked if they believe that the recent rise in affordable internet plans have aggravated piracy, 93\% responded on favour (Table 13).

\section{Conclusions}

This paper unlocks many forms of piracy prevailing in the society i.e cinematographic piracy, music and sound recording piracy, software piracy and books piracy. This is based on a detailed multistage stratified sampling for carrying out the surveys of students who are currently enrolled in various faculties in the University of Delhi. The definition of piracy is broadened to include four aspects i.e. unauthorised downloading, unauthorised duplication, purchasing pirated materials and photocopying of books. The paper lists some of the important features governing piracy like the frequency of using file sharing services and how the purchasing of original materials is been affected by it; any intention of using it in near future, views on peer piracy, awareness of the legal consequences of indulging in piracy and reasons for still persisting with it, role of affordable internet plans in aggravating piracy and finally, the reasons for not indulging in piracy. 
The most dominant form of piracy has come out to be downloading and copying (duplication) along with photocopying of books. Majority of the respondents cited fear of malwares as the most important reason followed by disliking for virtual copies, fear of loss of privacy and no access to computers, for not using file sharing services, despite showing their interest in using file sharing services in near future; majority agreed that online streaming and file sharing services have actually reduced their purchasing of original materials.

There is general acceptance of piracy among the people even though, people are unaware of legal consequences of engaging in piracy. People attributes this to overpricing of original materials; followed by easy to find stuffs online, ready availability, saves time as there is no need to visit the store and no prosecution worries. Finally, majority believed that recent rise in affordable internet plans have aggravated piracy.

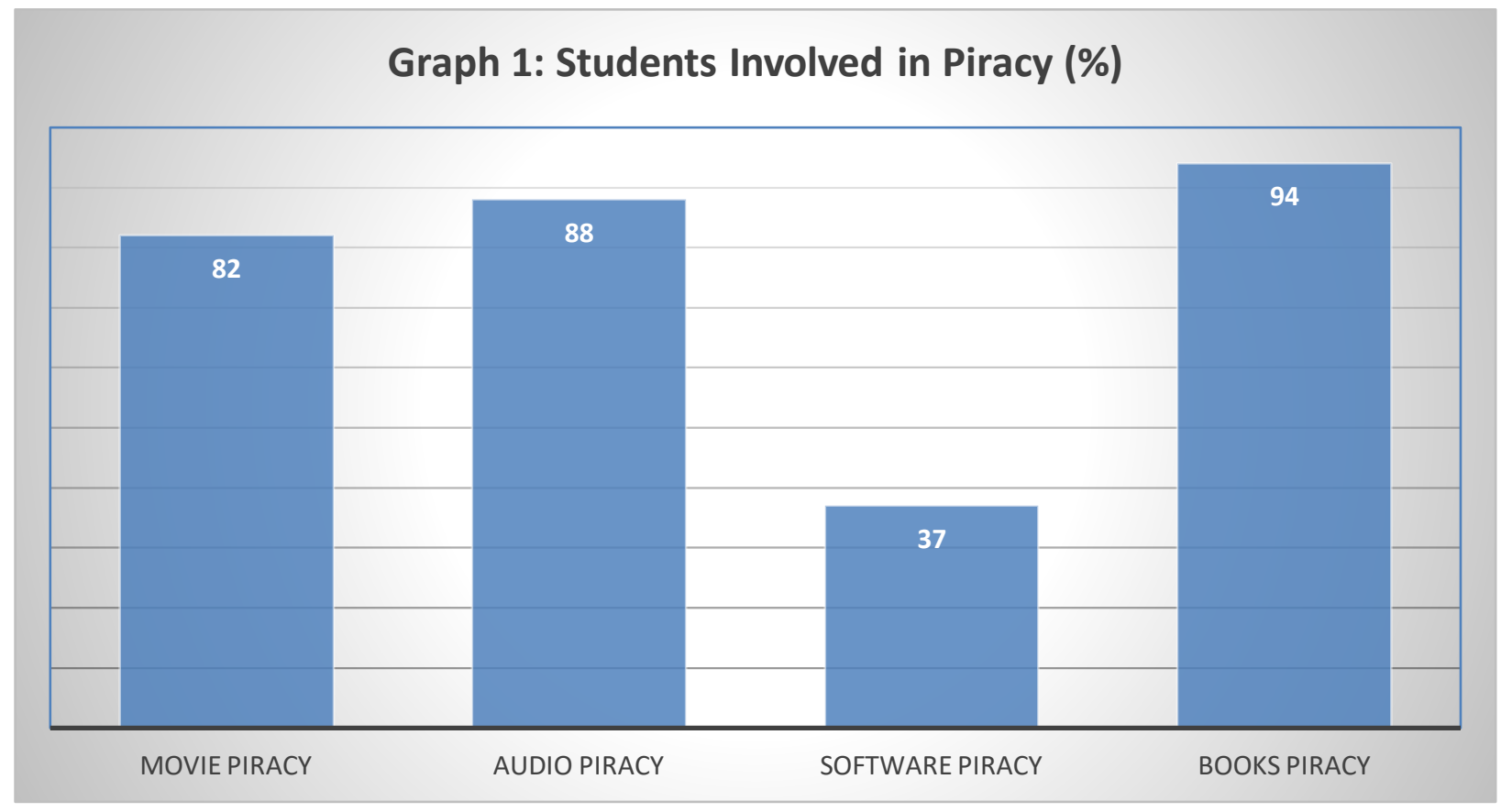


International Journal of Social Science and Economic Research

ISSN: 2455-8834

Volume:05, Issue:11 "November 2020"

\section{Graph 2: Number of Students Engaged in Movie Piracy}

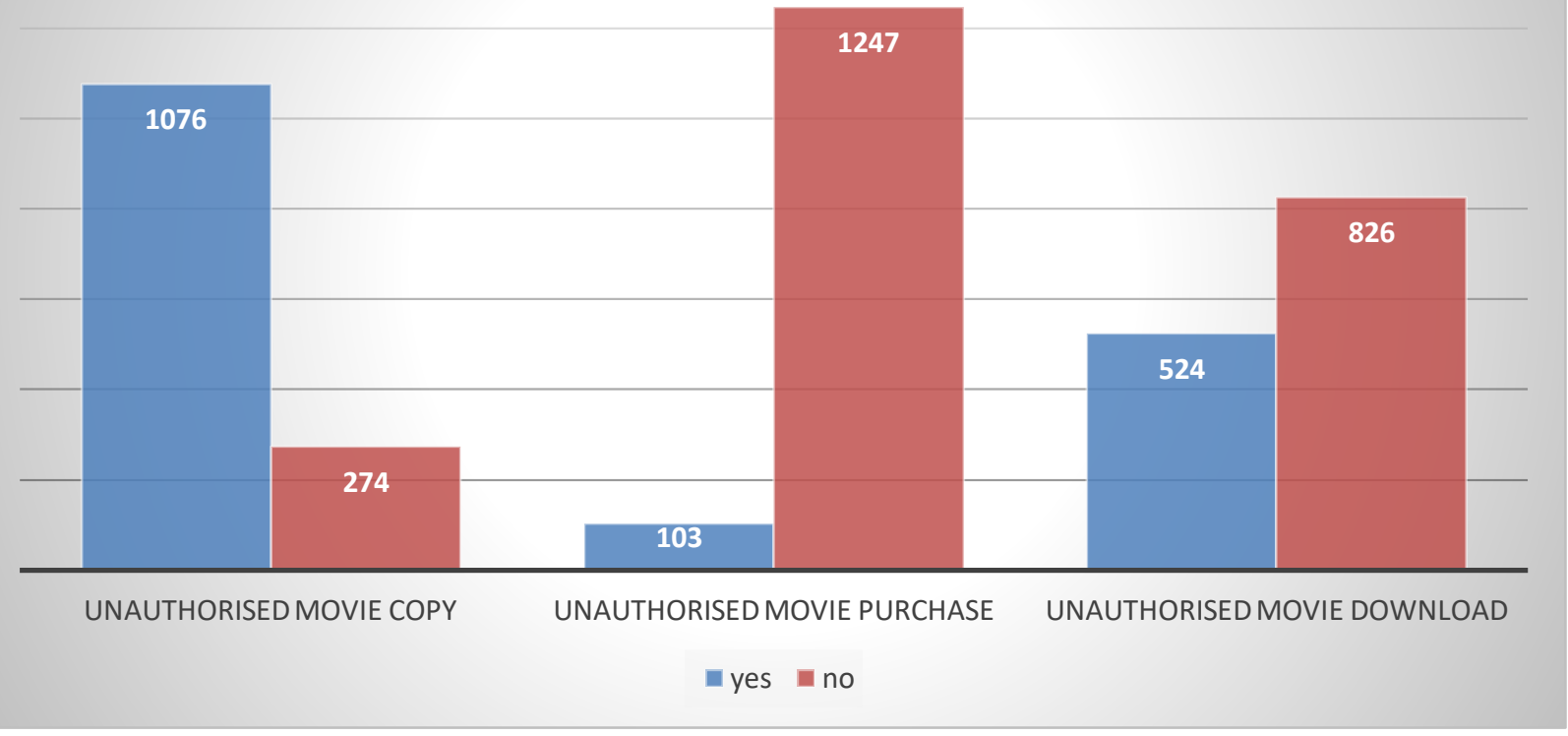

\section{Graph 3: Number of Students Engaged in Audio Piracy}

1400

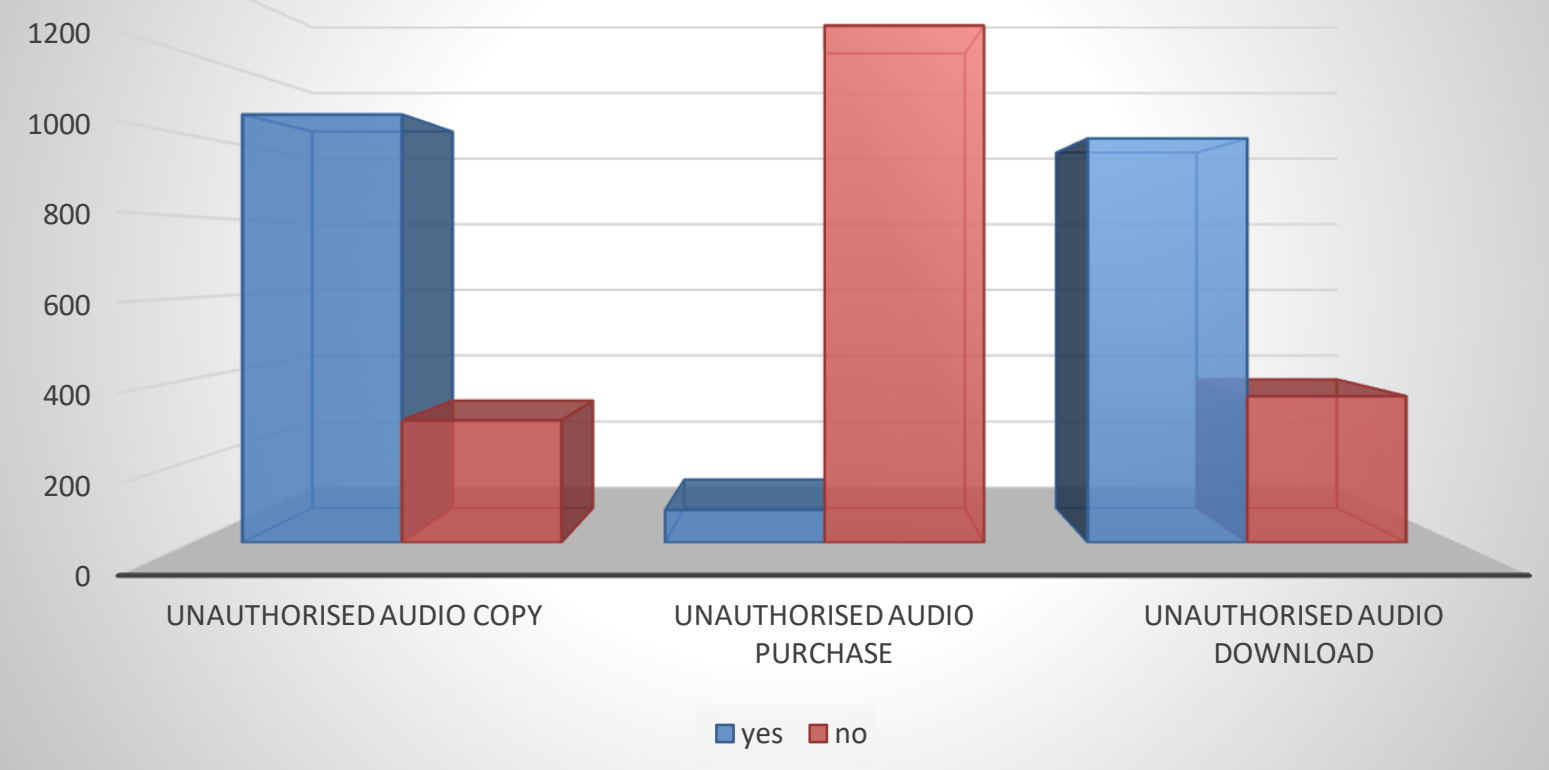


International Journal of Social Science and Economic Research

ISSN: 2455-8834

Volume:05, Issue:11 "November 2020"
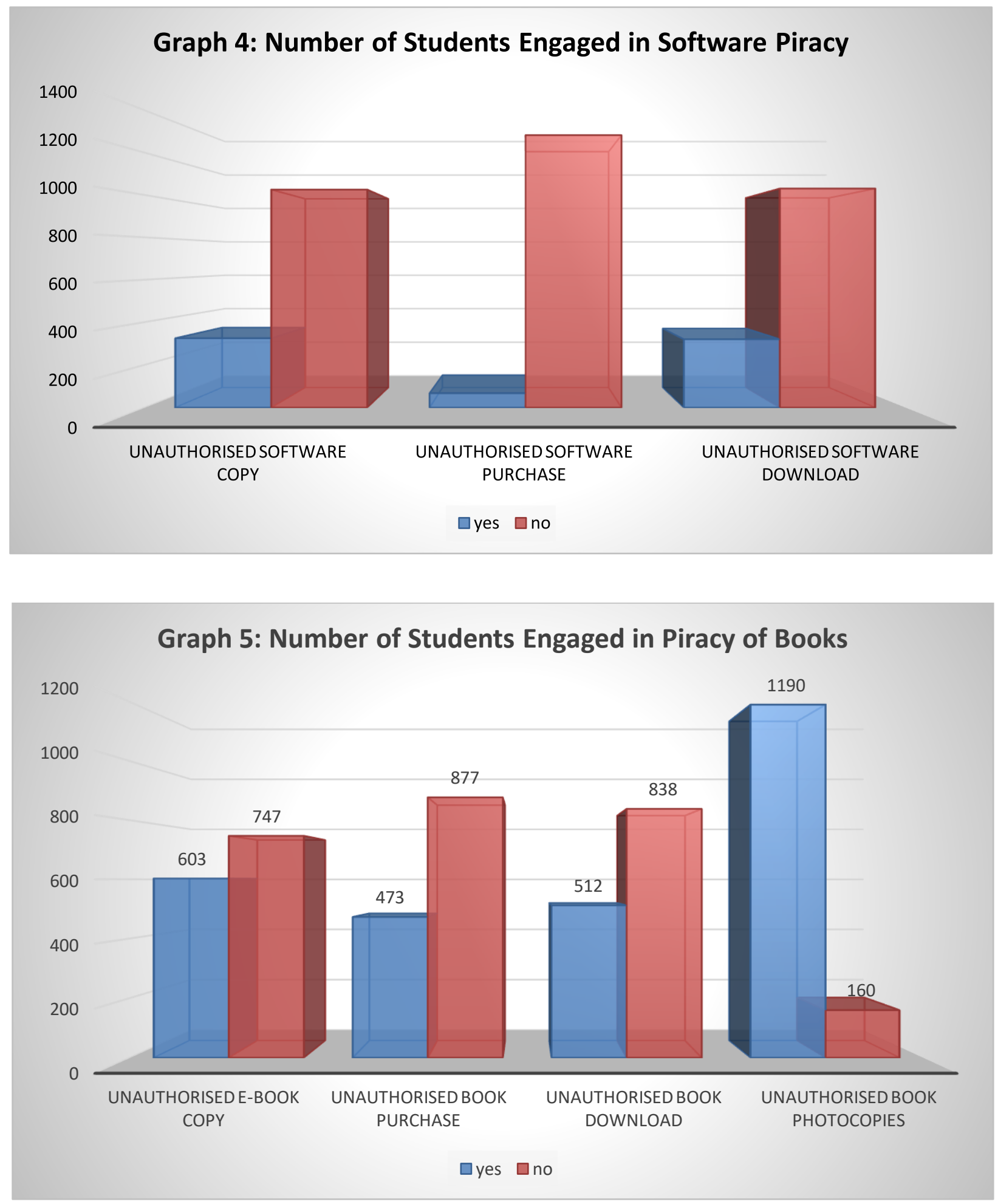
Table 6: Frequency of using File Sharing Services to download Movies, Music, Software and Books

\begin{tabular}{|l|l|}
\hline Frequency & Numbers of Respondents \\
\hline Once in a day & 245 \\
\hline At least once in a week & 566 \\
\hline At least once in month & 171 \\
\hline At least once in a year & 63 \\
\hline Not using such services & 274 \\
\hline
\end{tabular}

Table 7: Reasons for not using File Sharing Services to download Movies, Music, Software and Books for those who responded negatively in table 1

\begin{tabular}{|l|l|}
\hline Reasons & Numbers of Respondents \\
\hline No access to computer/laptops & 46 \\
\hline Loss of Privacy & 55 \\
\hline Fear of Malwares & 96 \\
\hline Doesn't have the knowledge of doing it & 38 \\
\hline Don't like soft copies & 58 \\
\hline Others & 20 \\
\hline
\end{tabular}

Table 8: Are you interested in using file sharing services and free downloading and have the intention to use it in near future?

\begin{tabular}{|l|l|}
\hline Likert Scale & Number of Respondents \\
\hline Yes, definitely & 223 \\
\hline
\end{tabular}




\begin{tabular}{|l|l|}
\hline Yes, probably & 896 \\
\hline No, probably not & 134 \\
\hline No, definitely not & 70 \\
\hline
\end{tabular}

Table 9: To what extent, would you say that online streaming or file-sharing services have affected your purchasing of original stuffs?

\begin{tabular}{|l|l|}
\hline Response & Numbers of Respondents \\
\hline I have stopped buying original stuffs & 117 \\
\hline It has made me buy less original stuffs & 992 \\
\hline It has not changed no. of original stuffs, I buy & 177 \\
\hline It has made me buy more original stuffs & 44 \\
\hline
\end{tabular}

Table 10: What is your opinion about that large numbers of your fellow students around you who download pirated music/movies/software/books online and share it with other people?

\begin{tabular}{|l|l|}
\hline Response & Numbers of Respondents \\
\hline I accept & 918 \\
\hline I am offended & 50 \\
\hline No comments & 360 \\
\hline
\end{tabular}

Table 11: If I tell you that engaging in piracy is illegal and it can invite both fine and/or jail term, would you stop doing it?

\section{Response}

Numbers of Respondents 


\begin{tabular}{|l|l|}
\hline No & 343 \\
\hline yes, I would stop immediately & 987 \\
\hline No comments & 20 \\
\hline
\end{tabular}

Table 12: If answer to the above question is 'No', then what is the reason behind it?

\begin{tabular}{|l|l|}
\hline Reasons & Numbers of Respondents \\
\hline $\begin{array}{l}\text { It save money as the original stuffs are } \\
\text { overpriced }\end{array}$ & 246 \\
\hline $\begin{array}{l}\text { It is convenient as pirated stuffs are readily } \\
\text { available }\end{array}$ & 45 \\
\hline $\begin{array}{l}\text { It saves my time with less visit to CDs/ } \\
\text { books/electronic stores }\end{array}$ & 41 \\
\hline It is a hobby for me to download & 9 \\
\hline $\begin{array}{l}\text { It is easy to find favourite } \\
\text { music/movies/software/books by search online }\end{array}$ & 66 \\
\hline I don't care about the law & 16 \\
\hline $\begin{array}{l}\text { I haven't seen anybody being prosecuted for } \\
\text { using pirated stuffs, so why I should worry }\end{array}$ & 41 \\
\hline Other reasons & 15 \\
\hline
\end{tabular}

Table 13: Would you support the view that recent rise in affordable internet plans have aggravated piracy?

\begin{tabular}{|l|l|}
\hline Likert Scale & Numbers of Respondents \\
\hline Definitely Yes & 806 \\
\hline Probably Yes & 447 \\
\hline
\end{tabular}


International Journal of Social Science and Economic Research

ISSN: 2455-8834

Volume:05, Issue:11 "November 2020"

\begin{tabular}{|l|l|}
\hline Probably No & 60 \\
\hline Definitely No & 14 \\
\hline
\end{tabular}

\section{References}

Cochran, W. G. (2007). Sampling techniques. John Wiley \& Sons.

Hansen, M. H., Hurwitz, W. N., \& Madow, W. G. (1953). Sample survey methods and theory. V. 1. Methods and applications. V. 2. Theory (No. $519.52 \mathrm{H} 249$ ). Wiley.

Kish, L. (1965). Survey sampling (No. 04; HN29, K5.).

Levy, P. S., \& Lemeshow, S. (2013). Sampling of populations: methods and applications. John Wiley \& Sons.

Thompson, S. K., Wilks, S., \& Shewhart, W. (2012). Stratified sampling. SK Thompson, Sampling, 139-156.

University of Delhi, $91^{\text {st }}$ annual report 2013-14

http://du.ac.in/du/index.php?mact=News,cntnt01,detail,0\&cntnt01articleid=5471\&cntnt01 returni $\mathrm{d}=83$ 